\title{
Study of Development for Entrepreneurial University
}

\author{
Wu Jing \\ Xijing University, \\ Shaanxi Xi'an ,China \\ e-mail: 925884122@qq.com \\ Guo Xiaorong \\ Xijing University, \\ Shaanxi Xi'an ,China \\ e-mail: 2941100857@qq.com
}

\author{
Niu Lichui \\ Xijing University, \\ Shaanxi Xi'an ,China \\ e-mail: 815765002 @qq.com \\ Song Yanxiang \\ Xijing University, \\ Shaanxi Xi'an ,China \\ e-mail: 1067803816@qq.com
}

\begin{abstract}
The development of corporate universities needs theoretical basis and practical operation. The development of higher education needs the combination of the theory and practice. There are a lot of common resources between corporate universities and higher education. Universityenterprise cooperation has become an important way of training with the development of higher education. The effective combination of institutions of higher learning and enterprises which become the important way to cultivate the innovative talents and applied talents. In this article, the introduction of entrepreneurial university is conducted; the development of the corporate universities is illustrated; the research subject and research focus on corporate universities are analyzed; the development of corporate universities, stage of development and angle are studied; the lack of theoretical research for corporate university is conducted. The effective utilization of resources for institutions of higher learning and enterprises which will be one of the important development direction. It is of great significance for the cultivation of engineering talent in China.
\end{abstract}

Keywords- Corporate university; Higher education; Talent training; University-enterprise cooperation; educational resources

\section{INTRODUCTION OF ENTERPRISE UNIVERSITIES}

Enterprise university is also called the corporate company. Enterprise university is refers to the capital contribution by the enterprise, with enterprise senior management personnel, first-class business school professor and professional training for teachers. The education of ideological and political education method, such as actual combat simulation, cases discussion, interactive teaching, etc. Middle and senior management personnel be conducted training in the enterprise. It satisfies people's lifelong learning needs of a new type of education and training system.

Morrison thinks companies such as the traditional training department is passive reaction, piecemeal, fragmented, while corporate universities of every kind of work for the enterprise to provide education and training related to strategy, and the education object in addition to the enterprise internal employee, also extended to corporate customers and suppliers [1].
El - Tannir through comparative analysis with traditional universities think the lack of corporate universities have [2] :

(1) Compared with the traditional university learning areas and learning subjects lack of breadth.

(2) Learning program at the university of enterprises lack of general recognition degree certification and project.

(3) Lack of university scientific research depth of academic research.

(4) Transfer learning content is usually restricted by time, and learning.

(5)The lack of the same pressure with the traditional university classroom environment.

(6) Lack the opportunity to communicate with traditional university the same freedom.

Anderson has criticized corporate university is a tool for the employees to post knowledge, however, teaching is usually focused on post operation method, like the traditional university business school offers diverse perspectives and broad experience [3].

Higher education views on corporate universities are: corporate universities are engaged in a lot of education cannot reach the level of higher education, their narrow subject coverage, teacher can only say that the employees instead of scholars, and the curriculum and content rarely involved in academic research. And think: because the university has developed more than 600 years, university education must bad college enterprise actual level; Corporate university is "interest". Some accuse corporate university deviated from the basic concept and the basic principle of higher education, such as academic freedom, freedom of the press, etc. Academic research and academic exchanges, however, is not the main aspects of the practice of corporate universities [4]. In addition, less a part of the corporate university can provide degree courses, one of the main reason is many corporate universities are not willing to, or think there is no need to pay the high price, so difficult to get the certification of the competent department of education, and traditional higher education institutions tend to spend too much time and effort, overcome various difficulties to get funds and strive for public recognition of the country. 


\section{DEVELOPMENT OF THE CORPORATE UNIVERSITIES}

\section{A. Corporate universities}

Corporate universities the historical origin of the earliest dates back to the school administrative office in a factory. The first half of the 19th century, in order to adapt to the industrial revolution

Exhibition, to adapt to the mechanization of production mode, the enterprise for workers, especially the education of mechanical workers movement vigorously throughout the UK. General electric in 1914, Charles Steinmetz advocacy to start a business school (Corporation Schools).

Business school founded is one of the important symbol of the burgeoning corporate universities. Since the $80 \mathrm{~s}$, due to the industry of science and technology innovation, production all kinds of knowledge update speed, in the field of practical training needs increasing, the development of the enterprises pay more attention to the knowledge and skills of the employee and the consistency of enterprise development, enterprises are more willing to pay for all the staff to provide training and education, to improve production efficiency and core competitiveness [5]. In the late $90 \mathrm{~s}$, some of the leadership of the enterprise level and the most advanced enterprise human resources Management aspect, or is a learning organization for the development of positioning of the enterprise beginning to university as a powerful and efficient tool to promote the organization and Management to make the necessary changes, to carry out its global strategy.

\section{B. Development status quo of corporate universities}

Corporate universities in our country in general is still in its infancy, but the momentum of development. In the global economic integration, in the process of China as an important emerging economies has become the important engine of world economic development, Chinese enterprises also received before. The unprecedented development, they are through constant specifications listed, through benchmarking learning progress, through extensive deeply involved in the world competition in the market constantly [6]. July 17 solstice 18, 2010, the first "China enterprise development of university BBS and CLO chief learning officer summit was held in Beijing, the BBS and summit by the Chinese society for the study of human resources development with the national development and reform committee will be jointly organized training center. According to information, the BBS sponsor reference multinational enterprise talent training mode of Chinese enterprises type, has been formally established more than three thousand corporate universities.

\section{Development situation of corporate universities}

(1) features manifest, a variety of forms

The vigorous development of the corporate university contributed to the development level, industry, service scope, financing mode and operation mechanism, the relationship between the organization, function structure each are not identical, the distinctive corporate universities. Enterprise university affiliated companies have total assets of less than $\$ 300$ million, fewer than 500 of the total number of employees of small enterprises. Belongs to its traditional industries such as food and beverage retail industry, there are information technology and other hightech industries, and the financial insurance and other highend services; Form a virtual network university form, also have real university form [7]. Service scope have special service of parent companies, there are services industry value chain, service industry and even the society at the same time to provide public services.

(2) the significant environmental impact

Into the era of knowledge economy, knowledge elements not only is the core of enterprise development strategic elements, but also the basic elements of enterprise development [8]. Economic globalization further sped up the knowledge update speed, expanded the scope of knowledge update, promote the technology innovation, industrial upgrading and change management. Enterprises rely more on the development of learning ability to adapt to the increasingly complex environment, the increasingly fierce market competition, corporate universities become service enterprise development strategy, cope with the challenge of development of the important tools, corporate universities based on specialized knowledge production services, systems and efficient learning solutions, improve the market competitiveness and sustainable development of the enterprise.

Corporate university arose in the information age, many enterprises at home and abroad at the university of positive application of information technology, artificial intelligence, network technology, multimedia technology, satellite communications, and even some enterprise priority to the development of university development or remote network virtual university. Especially for branches and operating points of services, such as postal service, telecommunications, finance, insurance, such as food and beverage retail chain operation, remote network learning has many irreplaceable advantages. In addition, based on information technology can effectively realize intelligent knowledge management, teaching management, multimedia teaching, intelligence, network collaborative learning and create a virtual learning community, etc. Information technology has become an important productivity of knowledge production, also provide support for the corporate universities great-leap-forward development of our country.

\section{ENTERPRISE RESEARCH SUBJECT AND RESEARCH AT THE UNIVERSITY OF KEY ANALYSIS}

\section{A. Research subject}

(1) consulting company. In the field of corporate university practice, provide for-profit market service corporate universities consulting company founded in operations management.

(2) universities and research institutions. Universities and research institutes of main advantage lies in the more comprehensive with associated with it corporate university study integrated disciplines in the higher education field of vision system, such as management, economics, pedagogy, psychology and so on, convenient for multidisciplinary collaboration, began to show system in-depth study. At the same time, with the industry and the relevant practice departments, research institutions, when conducting 
exchanges and cooperation in the field of theory research and summing up the experience of related.

(3) professional research institutes. Focus on corporate universities [9], on-the-job continue education non-profit professional research institutions including the government consists of the competent department in charge of education, labor and other research institutions and industry association of vocational education research institutions, universities and industry enterprise university union, etc.

\section{B. Research priorities}

(1) The enterprise management. Corporate university research perspectives more study from the perspective of enterprise management, pay more attention to corporate universities play a role in enterprise management, the function, how to design, create, manage and develop corporate universities to better serve the parent enterprise, how to better service to the parent company's business objectives, development strategy, organizational change, operation and management, the core business, cultural construction, performance improvement, human capital development, etc. From the point of subject fields, university research is more focus on enterprise management, human resource management, and other areas of the discipline, its research Angle of view and natural is the enterprise management, human resources management professional fields, such as Angle of view for research [10].

(2) The higher education. Existing higher education under the perspective of corporate universities, scholars are commonly used in the field of higher education discipline strictly "university" standard to judge corporate universities, don't think corporate university is academic, the lack of basic academic principle [11], do not have university qualifications, especially in the studies of discipline development, to meet the university level.

With the development of knowledge economy, corporate universities increasingly become important bridge between higher education and industry. For the lifelong education system, an important part of national innovation system, become an important force in developing a learning society, enterprise development of practice and theory research of higher education at the university of also more and more big, the influence of corporate universities will be more and more attention by the higher education field, especially the management idea of enterprise university and applied value in the realization of knowledge, let the human capital of experience is worth learning in higher education.

\section{RESEARCH AT THE UNIVERSITY OF THE DEVELOPMENT OF AN ENTERPRISE}

\section{A. Development of dynamic analysis}

Scholars at home and abroad agent have different opinions on the development of corporate universities. Taken together, the reason mainly has: the knowledge of economic and social development [12]. Knowledge update speed; Economic globalization trend; The market competition is increasingly intensified; The development of information technology. Enterprise organization's learning ability, knowledge innovation ability, human capital, intellectual capital has become increasingly important; As well as new and high technology industries, emerging after the development of industry and based on the urgent demand of proprietary knowledge of special education training. Corporate universities can effectively develop human capital and intellectual capital, and promote enterprise's learning ability, innovation ability to cope with the challenge of economic globalization and increasingly fierce market competition, can help employees to adapt to the transition and the new technology environment, can provide enterprises are in urgent need of specialized education system, enhance the competitiveness of the enterprises.

Corporate universities can enhance enterprise's profit ability, by promoting the staff's ability quality and its rapid into business

Good, and have measurable financial gains. Corporate universities as a centralized training tool, can revolve around the enterprise the management strategic target coordinate training and development activities, and help to integrate, plan as a whole, coordination, sharing and intensive management education and training resources, avoid waste of resources, redundant construction, make the enterprise education and training more cost-effective advantage and more investment value, it can also develop employees of global ideas, strategic awareness, interdepartmental coordination ability, etc.

\section{B. Development phase analysis}

Enterprise essential differences reflected in the different stage of development of the university of enterprise specialization of knowledge production service, the substantial demand for knowledge elements from limited to a certain direction to the overall demand, the function of corporate universities with core competence has been constantly improve and expand. Corporate universities also should reflect the nature of the differences in the different developmental stages of the development of knowledge elements supply ability, knowledge innovation ability, enterprise core competence, such as the organization's ability to learn, and play the role of core competence. Mature at the same time, the development of corporate universities also need external development environment of enterprise university system support, especially the knowledge of factor market mature and perfect, mature and diversified development, perfect higher education system and learning partners, such as education training to the common development of value chain members.

\section{CORPORATE UNIVERSITIES OF THE DEFECTS IN THE THEORY RESEARCH}

Enterprises to study practice ahead of theory research and practice to promote theoretical research, and research content are mostly focused on large enterprises

Learning practice areas, such as: best practices of corporate universities, the latest model and successful experience, the latest trends, etc [13]. Practice for study provides rich vivid material, and makes the research more targeted and practical. Especially research consultancy for corporate university practice developed practical templates, tools and methods; For creating operational management enterprise university provides guidance and support; And 
in a timely manner to reflect the enterprise of the latest developments in the university. However, based on the concept of corporate universities, development, motivation, stage of development, properties, characteristics, historical analysis of functional role it is not hard to see the study of the theory of the corporate university is still relatively weak, the enterprise of the university of theoretical construction remains to be perfect. At the university of enterprise nature, common characteristic and law of the development of organization, organization rules and corporate universities influence on modern higher education in the lack of a comprehensive system research, mainly manifested in the following aspects:

(1) Enterprise longitudinal historical research at the university of relatively insufficient.

Although some research expounds the development history of corporate universities, but the history of the scale and depth vision are relatively limited, limited in the development history of in-service education and training, failure to comprehensive look at the production practice of human society from the macroscopic level of knowledge in the field of hair exhibition, professional education development.

(2) Enterprise horizontal comparative study at the university of relatively insufficient.

University is not enough not enough in-depth study, enterprise nature of universities' organization and organization operation research and logic further. it is necessary to enterprise university and relevant similar organization to conduct a comprehensive in-depth comparative study of higher education.

(3) Enterprise common characteristic research at the university of relatively insufficient.

Due to large enterprise individual differences, and the industry development, institutional system, market environment, economy, culture idea many internal and external factors, such as, the influence of the corporate university best practices and successful experiences of replication and extension by certain limitations, so the common features, general rule and internal logic and essential attribute of the research is particularly important.

(4) Corporate university research Angle is relatively narrow.

Corporate universities lack of comprehensive research, lack of interdisciplinary research. Corporate university research is mostly in the field of practice from the perspective of business management, organization development, in view of the specific corporate university case study. Although the subject has different organizations such as the industry, academia, there are different disciplines such as management, education background, but the lack of extensive communication related disciplines, the lack of interdisciplinary collaborative research, mostly based on their respective discipline professional, practical experience and research basis to examine corporate university research.

\section{CONCLUSIONS}

The development of the corporate universities needs theoretical basis and practical operation. The development of higher education needs combination of the theory and practice. There are a lot of common resources between corporate universities and higher education. So to strengthen the rational use of resources that can promote the rapid development of the corporate universities. In this article, the introduction of entrepreneurial university is conducted; the development of the corporate universities is illustrated; the research subject and research focus on corporate universities are analyzed; the development of corporate universities, stage of development and angle are studied; the lack of theoretical research for corporate university is conducted. In order to promote the rapid development of the corporate universities, in order to meet the teaching needs of colleges and universities, in order to save the limited social resources, to promote employment, the combined of enterprise resources and university resources that will be one of the important development direction of enterprise university.

\section{REFERENCES}

[1] Zhang Jing. Enterprise university research [M]. Beijing: economic science press, $2011(8): 27$.

[2] El-Tannir, A. The Corporate University Model for Continuous Learning[J]. Training and Development, Education Training,2002,44(2):76-81.

[3] Anderson, L. Essential Part of Education Landscape: Corporate Universities - Virtual or Real - are Establishing Themselves Both in the US and in Europe[N]. Financial Times, 2002-03-25.

[4] Allen, Mark. Corporate Universities: Globalization and Greater Sophistication[J]. Journal of International Management Studies, 2010,5(10):48-53.

[5] Allen, Mark. Corporate Universities. Globalization and Greater Sophistication[J]. Journal of International Management Studies, 2010, 5(1): 48-53.

[6] LuiAbel. Exploring the corporate university phenomenon: Development and implementation of a comprehensive survey [J].human resource development quarterly. 2012. 23 (1) :26-31.

[7] Song Xiling. Based on the perspective of adult education enterprise development research at the university of $[\mathrm{J}]$. Journal of hubei university adult education college, 2012, (10).

[8] Wu Feng. Enterprises to study research, based on the perspective of learning innovation [M]. Beijing: Beijing humanism publishing house. 2013.

[9] Wu Feng. Based on the theory of enterprise model of human fields. Modern distance education research [J]. 2012, (3) : 75 - a - 79.

[10] Wu Feng, the silver. And the trend of development of the enterprise to study research field. The higher engineering education research [J]. 2012,(4) : November 16.

[11] Phillips,J. J..Return on investment in training and performance impmvement pronrams[M], Mass. :Butterworth - Heinemann. 2003.

[12] Xue Song li. Enterprises from four different point of view to study [J]. Engineering machinery today, 2009, (12): 124-126.

[13] Gao Qin and Long Yong, chang-lin ma, wen-liang guan. Mechanical and electrical integration of liquid system modeling and simulation technology [M]. Beijing: electronic industry press. 2012. 